\title{
Chemical Analysis of Soil Samples to Evaluate the Soil Fertility Status of Selected Command Areas of Three Tanks in Tiptur Taluk of Karnataka, India
}

\author{
A.M.Shivanna ${ }^{\#}$ and G.Nagendrappa* \\ \# Research fellow, DOS in Chemistry, University of Mysore, Manasagangotri, Mysore, India. \\ (Department of Chemistry, Kalpataru First grade Science College, Tiptur, Karnataka, India) \\ *Department of Studies in Chemistry, University of Mysore, Manasagangotri, Mysore, India.
}

\begin{abstract}
Nutrients present in a soil are the most important elements required for the healthy growth of plants and soil fertility is the status of the soil to supply nutrients to plants in adequate amounts and in suitable proportions. Soil fertility may be influenced by the water quality of the tanks used for irrigation. Study was conducted to evaluate the soil fertility status of selected command areas of three lakes- Eachanur, V. Mallenahalli and Halkurke in Tiptur taluk. The variables tested included pH, EC, OC, N, P, and K. The study revealed that the $\mathrm{pH}$ of the soil samples ranged from 7.07 to 7.87 and was on slightly alkaline side but within the limit of 6.5-8.5 which is optimum for crops. EC values ranged from $0.26 \mathrm{dSm} \mathrm{m}^{-1}$ to $0.485 \mathrm{dSm}^{-1}$ and were within the limit of $0.8 \mathrm{SSm}^{-1}$ indicating low salinity status of the soils. OC content ranged from $0.50 \%$ to $0.67 \%$ and all the samples were of medium rating. Available nitrogen ranged from $54.825 \mathrm{~kg} / \mathrm{ha}$ to $85.72 \mathrm{~kg} / \mathrm{ha}$; available phosphorous ranged from $5.33 \mathrm{~kg} / \mathrm{ha}$ to $10.79 \mathrm{~kg} / \mathrm{ha}$ and samples were nitrogen and phosphorous deficient. Potassium ranged from $156.18 \mathrm{~kg} / \mathrm{ha}$ to $434.38 \mathrm{~kg} / \mathrm{ha}$ and samples were of medium rating except one sample of high rating with respect to potassium.
\end{abstract}

Key words: lakes, nutrients, optimum, organic carbon, plant growth, soil fertility.

\section{Introduction}

Soil is the "soul" of infinite life and is generally refer to the loose material composed of weathered rock and other materials including partly decayed organic matter. It is a reservoir of nutrients and plays a pivotal role in supporting the growth of crops and other vegetation maintaining the earth's environment clean. It also acts as a source and sink for atmospheric gases[1]. Out of the total geographical area of 329mha of our country, about $265 \mathrm{mha}$ is suitable for crop production and about $175 \mathrm{mha}$ is affected by soil related constraints and are classified as waste lands. Soil erosion by water is a serious problem in the red and lateritic soils of south India and eastern India where about 40t/ha of top soil is lost annually and led to extinction of some unique flora and fauna of the region[2].

Elements carbon, oxygen and hydrogen which account for $95 \%$ of the plant needs are mostly obtained from air and water. The six elements nitrogen, phosphorous, potassium, magnesium, calcium and sulphur which are required in large quantities are labeled as macronutrients. Most of the soils supply enough calcium, magnesium and sulphur and soil scientists called these elements as secondary nutrient elements. The other three elements nitrogen, phosphorous and potassium are called as primary nutrients and are not usually available in large amounts which is enough for best growth and therefore are added through fertilization.

Soil fertility is the status or the inherent capacity of the soil to supply nutrients to plants in adequate amounts and in suitable proportions. Soil productivity is the capacity of the soil to produce crops with specific system of management and is expressed in terms of yields. Soil fertility and productivity are the key pillars for food production and soil quality is of equal significance in the background of soil degradation caused by many factors. Crop growth is influenced by aerial and soil environment. Suitable environment is necessary for better germination, growth and yield of crops. The higher nutrient availability is favourable when soil has higher water holding capacity, proper aeration and less soil strength or mechanical resistance. All productive soils may be fertile but all fertile soils need not be productive which may be due to problems like water logging, saline or alkaline conditions, adverse climate etc. Under these conditions, crop growth is restricted though the soil has sufficient amounts of nutrients. Hence soil fertility status may be defined in a modified way as "the capacity of the soil to produce crops economically and maintain the soil's health without deterioration". Again, under irrigation, soil and water compatibility is very important and otherwise the applied irrigation water may adversely affect the chemical and physical properties of the soil. Hence, determining the suitability of land for irrigation requires a thorough evaluation of the soil properties, the topography of the land within the field and the quality of water to be used for irrigation. Soil fertility, compatibility and erodability are the elements of soil quality and among them the decline in soil fertility problem endangers the maximum growth in productivity [3]. 
The concept of soil fertility includes not only the quantity of nutrients a soil contains but how well nutrients are protected from leaching, how available the nutrients are and how easily plant roots can function [4]. Depending upon the cropping pattern, leaching, erosion, etc soil loses a considerable amount of nutrients every year. Soil testing provides information regarding nutrient availability in soils which forms the basis for the fertilizer recommendations for maximum crop yield. It also helps in reducing excess and indiscriminate use of fertilizers, pesticides, fungicides etc which eventually cause pollution since farmers and planners are lack of knowledge regarding the quantity of these to be applied. A soil fertility map for a particular area can prove highly beneficial in guiding the farmers and planners in ascertaining the requirement of various fertilizers in a season/year and making projections for increased requirement based on cropping pattern and intensity [5]. There is an increasing pressure to reduce the application of fertilizers in commercial agriculture and minimize non-point sources of pollution of both surface and ground waters. Therefore, application of variable rather than uniform rates of fertilizer has been proposed to avoid the application of fertilizers where it will not be properly utilized by the crops $[6,7]$.

If agricultural productivity has to be increased, precision farming is desirable which is widely adopted in developed countries but yet to take firm ground in India. Tailoring the management practices carefully for the soil and crop that suits to different conditions found in each field is called precision farming [5]. Therefore fertilizer recommendations based on soil fertility status will be the first step towards precision farming which will also help to reduce non-point sources of pollution of water bodies.

Keeping these points in view, investigation was carried out to assess the fertility status of soil samples of some selected command areas in Tiptur taluk of Tumkur district. The soil of the study area is mainly of red loamy soil. Red soils are light textured, shallow to medium in depth and usually under layer by compact subsoil, fairly porous with low water holding capacity. They are generally poor in nitrogen, phosphorous and humus. Drought had hit the Taluk area since two years and there was very scanty rain in these years and the area is facing acute water problem.

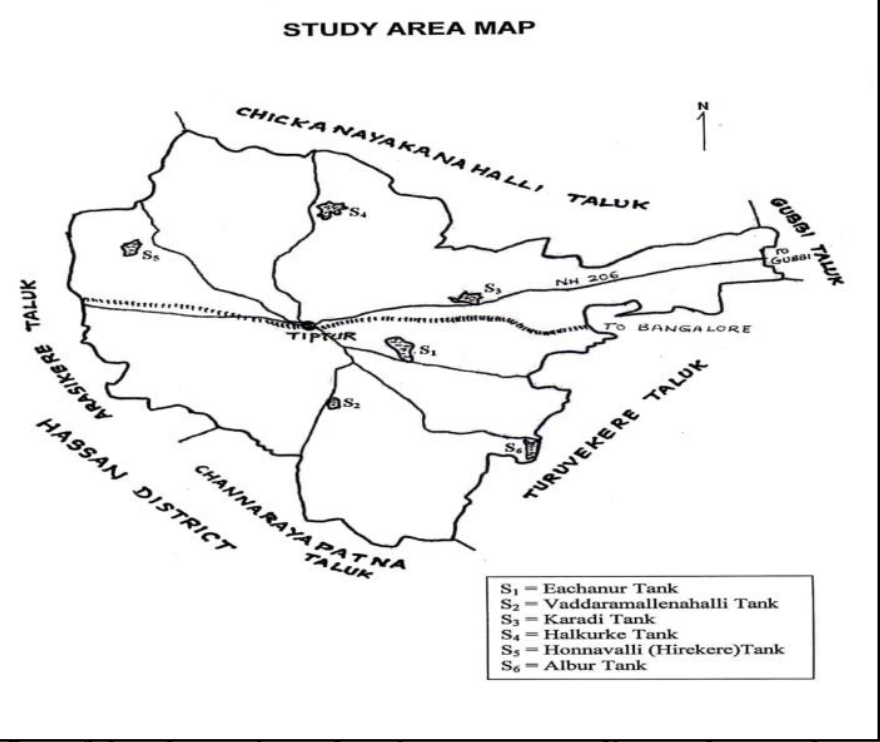

Fig-1 showing the study area: Out of the above six tanks where water quality study was done, soil study was carried out from the command areas of Eachanur, V. Mallenahalli and Halkurke tanks.

\section{Materials and methods}

For the characterization of the soil samples, a total of five representative model plots (each plot of about 5acre area)were selected out of which, two plots were from Halkurke tank command area, two from Eachanur tank command area and one from V. Mallenahalli tank command area in Tiptur taluk. From each selected plot, ten points were selected in a zig-zag path. Using soil auger, soil samples were taken at two different depths of $0-15 \mathrm{~cm}$ and $15-30 \mathrm{~cm}$ making a total of ten sub-samples for each depth. The samples of different depths were collected separately in polythene bags as per the standard procedures recommended by [8] and laboratory manual prepared by [9]. Quartering technique was used for the preparation of final soil samples. The soil samples were air dried, crushed and sieved through $2 \mathrm{~mm}$ sieve and stored in polythene bags for analysis. 
Soil $\mathrm{pH}$ in 1:2.5 solution (1Soil: 2.5Water) was determined using digital $\mathrm{pH}$ meter, EC was determined by digital conductivity meter. Organic carbon by [10], available phosphorous by [11] and available potassium by [12], nitrogen by micro Kjeldahl digestion and distillation method [13] were used during analysis.

\section{Results and discussion}

The physico-chemical characteristics and other parameters of the studied samples are given in table-1. 3.1 Soil pH: $\mathrm{pH}$ is another factor in addition to organic matter, soil phosphorous and calcium carbonate that influences the transformation and availability of micronutrients to plants. Acidity increases the availability of iron, manganese and copper where as alkalinity increases the availability of molybdenum [2]. When depth wise values were considered, $0-15 \mathrm{~cm}$ samples show lower $\mathrm{pH}$ when compared to $15-30 \mathrm{~cm}$ depth (deeper) soil samples. The low $\mathrm{pH}$ values could be due to low level of organic matter and leaching of some of the nutrient elements [4].

$\mathrm{pH}$ values of the soil samples from two sites of Halkurke command area were 7.07 and 7.54 with an average of 7.3. $\mathrm{pH}$ values of the soil samples from two sites of Eachanur tank command area were 7.87 and 7.84 with an average value of 7.85. $\mathrm{pH}$ value of $\mathrm{V}$. Mallenahalli tank command area was 7.52. The soil samples were slightly alkaline but $\mathrm{pH}$ of all the samples was within 6.5 to 8.5 range and was optimum for crops.

Table-1: Showing the observed soil characteristics of the samples taking average of the two depths.

\begin{tabular}{|c|c|c|c|c|c|c|c|}
\hline SI.No & $\begin{array}{c}\text { Sample } \\
\text { Details }\end{array}$ & $\mathbf{p H}$ & $\begin{array}{c}\mathbf{E C} \\
\left.\mathbf{d S m}^{-1}\right)\end{array}$ & $\begin{array}{c}\mathbf{O C} \\
(\mathbf{\%})\end{array}$ & $\begin{array}{c}\mathbf{N} \\
(\mathbf{K g} / \mathbf{h a})\end{array}$ & $\begin{array}{c}\mathbf{P} \\
(\mathbf{K g} / \mathbf{h a})\end{array}$ & $\begin{array}{c}\mathbf{K} \\
(\mathbf{K g} / \mathbf{h a})\end{array}$ \\
\hline 1 & Ha-1 & 7.07 & 0.26 & 0.61 & 62.445 & 5.33 & 434.38 \\
\hline 2 & Ha-2 & 7.54 & 0.33 & 0.57 & 54.825 & 9.86 & 213.35 \\
\hline 3 & Ea-1 & 7.87 & 0.485 & 0.63 & 77.925 & 5.60 & 156.18 \\
\hline 4 & Ea-2 & 7.84 & 0.305 & 0.67 & 77.925 & 10.79 & 271.9 \\
\hline 5 & V.M & 7.52 & 0.265 & 0.50 & 85.72 & 6.26 & 169.98 \\
\hline
\end{tabular}

Ha-1 = Halkurke-1, Ha-2= Halkurke-2; Ea-1= Eachanur-1, Ea-2= Eachanur-2; V.M= V. Mallenahalli soil sample.

3.2 Electrical conductivity $(\boldsymbol{E C})$ : Electrical conductivity is a measure of soil's salt content or salinity level. Electrical conductivity of Halkurke soil samples were $0.26 \mathrm{dSm}^{-1}$ and $0.33 \mathrm{dSm}^{-1}$ at the two sampled areas and the soils were of low salinity class as EC was $<0.8 \mathrm{dSm}^{-1}$.

EC values of Eachanur soil samples were $0.485 \mathrm{dSm}^{-1}$ and $0.305 \mathrm{dSm}^{-1}$ respectively and EC value of V. Mallenahalli soil sample was $0.265 \mathrm{dSm}^{-1}$. EC values of all the soil samples were within $0.8 \mathrm{dSm}^{-1}$ indicating the normal nature of soils and belong to low salinity class. The electrical conductivity of $4 \mathrm{dSm}^{-1}$ at $25^{\circ} \mathrm{C}$ has been taken, in general, as the limit for categorizing soils as beyond this level, the yield of most of the common field crops is lowered [14]. Plant response due to salinity effect is negligible when EC value of the saturation extract is $0-2 \mathrm{dSm}^{-1}$.

If water quality of these tanks were considered to see the effect on soils, mean EC of Eachanur tank water was $0.209 \mathrm{dSm}^{-1}$ and that of $\mathrm{V}$. Mallenahalli tank water was $0.18 \mathrm{dSm}^{-1}$ and these waters pose low or no salinity effect upon use as their EC values were $<0.70 \mathrm{dSm}^{-1}$ and TDS values were $<450 \mathrm{mg} / \mathrm{L}$.

Mean value of EC of Halkurke tank water was $0.91 \mathrm{dSm}^{-1}$ on considering the two year average and the water was having slight to moderate restrictions on usage as its EC value was in $0.70-3.0 \mathrm{dSm}^{-1}$ range. This moderate quality was also confirmed from their TDS values which lie in the moderate quality range of $450 \mathrm{mg} / \mathrm{L}$ to $2000 \mathrm{mg} / \mathrm{L}$. The salts present in water sample is not only affecting the growth of plants directly but also affect the soil structure, permeability and aeration which will indirectly affect the plant growth [15].

Therefore care should be taken in selecting the crop and proper management is also required if full yield is to be achieved. Leaching of salts out of root zone must be practiced, when necessary, to avoid salt accumulation that may ultimately affect the crop production. The leaching necessary for a particular crop is to be estimated and should be used [16, 17]. In areas where a build-up of soil salinity cannot be controlled, an alternative crop can be selected that is both more tolerant of the expected soil salinity and can produce economical yields $[18,19]$. Adequate drainage is equally important and long term salinity control is not otherwise possible.

According to [20], tank water of V. Mallenahalli was not suitable for irrigation as its SAR was in 03range and EC was $<0.2 \mathrm{dSm}^{-1}$ and causes infiltration problem if used for irrigation. Slight to moderate infiltration problem was found with Eachanur tank water as the SAR value of this tank was in 0-3 range and EC value was in $0.70-0.20 \mathrm{dSm}^{-1}$ range. Similar problem exists with water of Halkurke tank which had SAR in 6-12 and EC in $1.90-0.50 \mathrm{dSm}^{-1}$ range. The fact that water quality of the said tanks is not good and if used for irrigation will cause infiltration problem was already reported in the journal article [21]. In sodic soils or sodium affected soils, sodium ions have become attached to and adsorbed on the soil particles. This causes a breakdown 
in soil structure and results in soil sealing or "cementing", making it difficult for water to infiltrate. Such an effect may also be found even when calcium and magnesium levels are low. Such results were observed when soils tests in command areas of Halkurke tank, Eachanur tank and V.Mallenahalli tanks were carried out and these soils were hard, compact and encrusted.

Table-2: Interpretation of soil rating based on OC (\%), N, P and K (reproduced from [8])

\begin{tabular}{|l|l|l|l|l|}
\hline Rating & $\mathrm{OC}(\%)$ & $\mathrm{N}(\mathrm{kg} / \mathrm{ha})$ & $\mathrm{P}(\mathrm{kg} / \mathrm{ha})$ & $\mathrm{K}(\mathrm{kg} / \mathrm{ha})$ \\
\hline Low & $<0.5$ & $<280$ & $<22.9$ & $<141$ \\
\hline Medium & $0.5-0.75$ & $280-560$ & $22.9-56.33$ & $141-336$ \\
\hline High & $>0.75$ & $>560$ & $>56.33$ & $>336$ \\
\hline
\end{tabular}

3.3. Organic carbon $(O C)$ : Organic carbon is another influential factor which increases the availability of iron and boron but decreases the availability of manganese, zinc and copper to the plants. In Halkurke soil samples organic carbon was $0.67 \%$ and $0.57 \%$ and the soil was of medium quality rating as per table-2. OC contents of Eachanur soil samples were $0.63 \%$ and $0.67 \%$ respectively and OC of V. Mallenahalli soil sample was $0.50 \%$ and these samples were also of medium quality rating. All the soil samples belong to medium class as their OC was in 0.5 to $0.75 \%$ range. The low $\mathrm{OC}$ can be attributed to continuous cultivation, removal of crops residues without return, effects of water and wind erosion which preferentially remove the soil colloids including the humidified organic fractions [4].

3.4 Nitrogen: Nitrogen which is a constituent of chlorophyll, increases vegetative growth of protein content and cation exchange capacity of plant roots. Its deficiency results in stunted growth of plants, shedding of leaves and fruits. Excess of nitrogen is also a problem to the plant which will be reflected by the delayed maturity and susceptibility to insects and diseases. Available nitrogen in Halkurke soil samples was $62.445 \mathrm{~kg} / \mathrm{ha}$ and $54.825 \mathrm{~kg} / \mathrm{ha}$ respectively which indicate that the soil was poor in nitrogen and was of low rating soil. Available nitrogen found in Eachanur soil samples was $77.92 \mathrm{~kg} / \mathrm{ha}$ and $77.92 \mathrm{~kg} / \mathrm{ha}$ where as it was $85.72 \mathrm{~kg} / \mathrm{ha}$ in V. Mallenahalli soil sample which are also poor in nitrogen.

All the samples have low nitrogen content as per the classification mentioned in table-2. Relatively low nitrogen was recorded in Halkurke soil samples which are open dry fields and are under continuous exposure to sunlight and wind. Low nitrogen content can be attributed to the fact that all the factors leading to the loss of nitrogen are prevailing in the study area which include high temperature leading to volatilization, erosion and crop removal and insufficient rain. Relatively high nitrogen content of V. Mallenahalli sample was because it was collected from coconut garden.

3.5 Available phosphorous: This is another important nutrient which helps in cell division, stimulates root growth and formation, makes plant more tolerant to drought, cold, insects and diseases, increases nodule formation in pulses. The available phosphorous depends on $\mathrm{pH}$ and OC. The near neutral $\mathrm{pH}$ has a significant role in enhancing phosphorous availability. The available phosphorous content increases with $\mathrm{pH}$ value and decreases with organic carbon. The increase in phosphorous due to increase in $\mathrm{pH}$ may be due to lowering of activities of $\mathrm{Fe}^{3+}$ and $\mathrm{Al}^{3+}$ which increases the solubility of strangle and variscite and increases electronegativity of colloidal complex with a consequent decrease in sorption of phosphorous [5].

Available phosphorous content in Halkurke soil samples were $5.33 \mathrm{~kg} / \mathrm{ha}$ and $9.86 \mathrm{~kg} / \mathrm{ha}$ and the soil samples were very poor in phosphorous. In Eachanur soil samples available phosphorous content was $5.60 \mathrm{~kg} / \mathrm{ha}$ and $10.79 \mathrm{~kg} / \mathrm{ha}$ respectively where as in V. Mallenahalli soil sample it was $6.26 \mathrm{~kg} / \mathrm{ha}$, which reveals that all soils were of low quality as per the interpretation made in table-2. When deficiency occurs, it causes stunted growth, reduces the size of leaves and delays maturity. The low phosphorous content can be as a result of low clay content and high sand particles, which lead to loss of soluble available phosphorous either by rain or acidification; effect of phosphorous fixation by the soil flora and other soil micro organisms [4]. The department of agriculture has launched a mission mode project, "Bhoochetana" and facilitated by International crops Research Institute for the Semi-Arid tropics (ICRISAT) to harness science for sustainable use of natural resources among farmers and increase rain fed crop yields by $20 \%$ in 30 districts of Karnataka. ICRISAT in its soil study report also revealed that Karnataka soils are critically deficient in Nitrogen and phosphorous along with micronutrients zinc, boron and sulphur. The same report reveals that Tiptur soils have neutral pH, deficient in organic carbon, nitrogen, phosphorous but normal potassium and our findings were in conformity with that report.

3.6 Potassium: The role of this element in plants is to impart vigour and growth, making plant more tolerant to drought, cold, insects and diseases, increasing the availability of nitrogen and phosphorous and increasing the size of root and tuber. Potassium deficiency is exhibited by marginal leaves turning brown and drying and stunted growth. Potassium content in Halkurke soil samples was $434.38 \mathrm{~kg} / \mathrm{ha}$ and $213.35 \mathrm{~kg} / \mathrm{ha}$ which belong to high and medium rating respectively. Potassium content in Eachanur soil samples was $156.18 \mathrm{~kg} / \mathrm{ha}$ and $271.9 \mathrm{~kg} / \mathrm{ha}$ where as in V. Mallenahalli soil sample it was $169.98 \mathrm{~kg} / \mathrm{ha}$ and these soil samples belong to medium 
rating in terms of potassium content (as per the interpretation rating shown in table-2). The higher available potassium content may be attributed to the prevalence of elite potassium rich mineral in these soils [21, 22].

\section{Conclusion}

Soils were slightly alkaline and belong to low salinity class and are neutral in nature. Nitrogen and phosphorous content was low in all soils; potassium was medium except in one sample of Halkurke sample where it was high. Hence these essential elements are to be supplemented through the addition of fertilizers in proper amounts which will bring maximum crop yield avoiding the pollution and saving the soil's health which harbours millions of microorganisms favouring the plant growth. Assessment of water quality and soil quality should be done as compatibility between soil and water is required for maximum yield and crop selection may be done based on this so that farmers get maximum benefit. Soil pollution and pollution of water bodies will be minimised as indiscriminate use of fertilizer is going to be avoided. Government and other organizations should take up the responsibility of giving awareness to stakeholders regarding the importance of soil and water quality testing.

\section{Acknowledgements}

The first author is grateful to Kalpataru Vidya Samsthe and The Principal of Kalpataru First grade science college, Tiptur, for their continuous support and encouragement to complete this work. The author is also grateful to National Bureau of Soil Survey, Bangalore and Regional research station of University of agricultural sciences (Bangalore), Konehalli, Tiptur taluk, for their technical support and the University of Mysore for giving the opportunity to take up this work.

\section{References}

[1]. Ratan Chand Sharma and Shivani Dogra, Characterization of the soils of Lower Himalayas of Himachal Pradesh, India, Nature Environment and Pollution Technology, Vol. 10(3), 2011, 439-446.

[2]. Katyal J.C , J. Indian Soc Soil Sci., 51, 2003, 378-387.

[3]. Pujar A.S, Yadawe M.S, Pujeri U.S, Pujari K.G and S.C.Hiremath Assessment of soil fertility of Grape field at Bijapur district, Karnataka, India, e- journal of Chemistry, 7(4), 2010, 1304-1307.

[4]. Sanda Ahmad R and Ismail Y.M, Soil fertility assessment of Research and Teaching farm of Audu Bako college of Agriculture Danbatta, Kano State, Nigeria, Nature Environment and Pollution Technology, Vol. 11(4), 2012, 639-642.

[5]. Larsen W.E and Robert P.C Farming by Soil, In soil water conservation society, Ankey, 1991, 103-112.

[6]. Miller M.P, Singer M.J and Nelson D.R, Spatial variability of wheat yield and soil properties on complex hills, Soil Sci. Soc. Am. J; 52, 1988, 1133-1141.

[7]. Trivedy R.K and P.K. Goel, Chemical and biological methods for water pollution studies, (Environmental publications, Karad, 1986).

[8]. Srinivasamurthy C.A, Ramakrishna Parama V.R, Hanumantharaju T.H and Sudhir Practical manual for hands on training/experimental learning, ( Department of soil science and agricultural chemistry, College of Agricultural Sciences, GKVK, Bangalore, 2010).

[9]. Walkley A and Black C. A, An examination of digestion methods for determining soil organic matter and a proposed modifications of the chromic acid titration method. Soil Sci., 37, 1934, 29-38.

[10]. Olsen S.R, Cole C.V, Watanabe F.S and Dean I A, USDA Circ. 1954, 939, 1-19.

[11]. Jackson M.L, Soil Chemical Analysis, (Prentice Hall, Inc. Eaglewood Cliffs, N.Y. 1962, pp 219-221).

[12]. Jackson M.L, Soil Chemical Analysis, (Prentice Hall India Pvt.Ltd. New Delhi 1967), p-498.

[13]. Varma K.K, Patel L.B, Toor G.S and Sharma P.K, Int. J. of Agriculture and Biology; 2, 2005, $295-297$.

[14]. Patel L.B, Varma V.K, Toor G.S and Sharma P.K, Beneficial plant nutrient supply from ground water of arid tract of Punjab, Ecol. Env. and cons., 6, 2000,105-108.

[15]. Jain, C.K., Bhatia, K.K.S., Kumar, C.P. and Purandara, B.K, Irrigation water quality in Malaprabha sub-basin, Karnataka. Indian Journal of Environmental Protection, 21(4), 2001, 348-354.

[16]. Rhoades J.D, Drainage for salinity control. In: Drainage for agriculture. Van Schilfgarde J (ed.). Amer. Soc. Argon. Monograph no.17. 1974, pp: 433-462.

[17]. Rhoades J.D and Merrill S.D, Assessing the suitability of water for irrigation: Theoretical and empirical approaches. In: Prognosis of salinity and alkalinity. FAO Soils Bull. 31, 1976, 69-110.

[18]. Maas E.V and Hoffman G.J, Crop salt tolerance-current assessment, J. Irrigation Drainage Div. ASCE 103(IRZ), 1977, 115-134, Proc. Paper 12993.

[19]. Maas E.V, Salt tolerance of plants. In: The handbook of plant science in agriculture. (B.R. Christie (ed.) CRC press, Boca Raton, Florida, 1984).

[20]. Ayers, R.S. and D.W. Westcot, Water Quality for Agriculture, Irrigation and Drainage Paper No.29. 1989, Food and Agriculture Organization of the United Nations, Rome.

[21]. Shivanna. A.M. Vijayabhaskar. C and G. Nagendrappa, Water quality assessment of certain selected tank waters of Tiptur taluk, Karnataka, for irrigation purpose, Nature Environment and Pollution Technology, Vol.11, No.2, 2012;pp 283-287.

[22]. Yellamanda Reddy, Y and G.H. Sankara Reddi, Principles of Agronomy; $3^{\text {rd }}$ revised edn. (Kalyani publishers, New Delhi2002).

[23]. Biswas T.D and S.K.Mukherjee, Text book of soil science, $2^{\text {nd }}$ edn. V reprint, (Tata Mc Graw-Hill Publishing Co. Ltd, New Delhi,1999,p-402). 